Artículo científico

Volumen 30(3):705-719. Septiembre-diciembre, 2019

e-ISSN 2215-3608, doi:10.15517/am.v30i3.34490

http://www.revistas.ucr.ac.cr/index.php/agromeso

\title{
Variability of the total oil content and fatty acid profile of creole avocados from Nuevo Leon, Mexico ${ }^{1}$
}

\section{Variabilidad del contenido total de aceite y perfil de ácidos grasos de aguacates criollos de Nuevo León, México}

\author{
Efraín Acosta-Díazz, María Genoveva Álvarez-Ojeda³, Salvador Horacio Guzmán-Maldonado \\ Isidro Humberto Almeyda-León ${ }^{2}$
}

1 Receipt: October 12 ${ }^{\text {th }}, 2018$. Acceptation: March 13 ${ }^{\text {th }}$, 2019.This work was part of the research project "Selection of avocado creole materials of Nuevo Leon, using molecular markets". Instituto Nacional de Investigaciones Forestales, Agricolas y Pecuarias, Mexico.

2 Instituto Nacional de Investigaciones Forestales, Agricolas y Pecuarias. General Teran Experimental Field. Km 31, route MontemorelosChina, ex-hacienda Las Anacuas, C.P. 67400. General Teran, Nuevo Leon, Mexico. acosta.efrain@inifap.gob.mx; almeyda.isidro@inifap. gob.mx (author for correspondence, https://orcid.org/0000-0002-8790-4437).

3 Instituto Nacional de Investigaciones Forestales, Agricolas y Pecuarias. Rio Bravo Experimental Field. Km 61, route Matamoros - Reynosa, C.P. 88900. Rio Bravo, Tamaulipas, Mexico. alvarez.genoveva@inifap.gob.mx

4 Instituto Nacional de Investigaciones Forestales, Agricolas y Pecuarias, Bajio Experimental Field. Route Celaya-San Miguel de Allende, Celaya, Guanajuato, Mexico.guzman.horacio@inifap.gob.mx

\begin{abstract}
Introduction. The State of Nuevo Leon is considered the depositary of a wide genetic diversity of creole avocados (Persea americana var drimyfolia). Objective. The aim of this work was to determine the variability of the total oil content and the fatty acids profile in creole avocados from Nuevo Leon, Mexico. Materials and methods. During the spring and summer of 2016, 36 varieties of creole avocados were collected in the northern and southern region of the State of Nuevo Leon, Mexico for chemical characterization. The commercial variety "Hass" was included as a control. To determine the variability that exists in the content of total oils and fatty acids in the collected materials, analyzes of the main components and conglomerates were carried out. Results. Six fatty acids were detected in the total oil of the creole avocados: palmitic, stearic, oleic, palmitoleic, linoleic and linolenic. The outstanding varieties were "Platano temprano", "Platano delgado", "Huevo de toro", "Cuerno", "Pato", and "Especial", which presented an average of $17.28,24.93$ and $66.29 \%$ more in the content of oleic, linoleic and linolenic acids respectively, and an average of $28.12 \%$ less stearic acid compared to the commercial variety "Hass". According to the analysis of main components, materials with high oleic acid content usually have low palmitic and palmitoleic acid contents. The dendrogram presented six groups within the evaluated materials, most of the outstanding materials are located in groups one and four. Conclusion. High variability in the content of total oils and fatty acids was determined in creole avocados from Nuevo Leon. Therefore, they are considered promising for their incorporation into genetic improvement programs.
\end{abstract}

Keywords: genetic resources, Persea americana, saturated fatty acids, polyunsaturated fatty acids.

\section{Resumen}

Introducción. El Estado de Nuevo León se considera depositario de una amplia diversidad genética de aguacates criollos (Persea americana var drimyfolia). Objetivo. El objetivo de este trabajo fue determinar la variabilidad del 
contenido total de aceite y el perfil de los ácidos grasos en los aguacates criollos de Nuevo León, México. Materiales y métodos. Durante la primavera y el verano de 2016, se recolectaron 36 variedades de aguacates criollos en la región norte y sur del Estado de Nuevo León, México para su caracterización química. La variedad comercial "Hass" fue incluida como control. Para determinar la variabilidad que existe en el contenido de aceites totales y de ácidos grasos en los materiales recolectados, se realizaron análisis de componentes principales y de conglomerados. Resultados. Se detectaron seis ácidos grasos en el aceite total de las variedades de aguacate criollo: palmítico, esteárico, oleico, palmitoleico, linoleico y linolénico. Las variedades "Plátano temprano", "Plátano delgado", "Huevo de toro", "Cuerno", "Pato" y "Especial", mostraron en promedio 17,28, 24,93 y 66,29 \% más en el contenido de ácidos oleico, linoleico y linolénico, respectivamente, y un promedio de 28,12 \% menos de ácido esteárico en comparación con la variedad comercial "Hass". De acuerdo al análisis de componentes principales, los materiales con altos contenidos de ácido oleico, por lo general tienen bajos contenidos de los ácidos palmítico y palmitoleico. El dendograma presentó seis grupos con los materiales evaluados, la mayoría de los materiales sobresalientes quedaron ubicados en los grupos uno y cuatro. Conclusión. Se determinó una alta variabilidad en el contenido de aceites totales y ácidos grasos en los aguacates criollos de Nuevo León. Por lo tanto, se consideran promisorios para su incorporación a programas de mejoramiento genético.

Palabras clave: recursos genéticos, Persea americana, ácidos grasos saturados, ácidos grasos poliinsaturados.

\section{Introduction}

Influenced by evolutionary forces and human selection, avocado has transitioned from small fruit forms native in the mountains of east and central Mexico and the highlands of Guatemala, to the cultivated forms distributed worldwide (Barrientos et al., 2010). Three avocado races are now recognized: Mexican (Persea americana var. drymifolia), Guatemalan (P. americana var. guatemalensis), and Antillean (P. americana var. americana). Differences among those races are based on morphological, physiological, and crop characteristics (Barrientos et al., 2010). The discovery of primitive avocados from the Sierra Madre Oriental in Nuevo Leon to Costa Rica suggests that the subgenus Persea originated in this area (Sánchez, 2007).

The majority of avocado varieties now cultivated in Mexico are interracial hybrids. Important varieties such as "Hass", "Bacon", and "Fuertes" are produced by crossing the Mexican and Guatemalan races (Newett et al., 2002). The Mexican race includes landrace varieties with regional names, whose fruit is locally sold and consumed. Also, these genotypes also provide rootstocks for the "Hass" variety of which Mexico is the main exporter (SAGARPA, 2016), and has the greatest worldwide distribution (Fiedler et al., 1998). Several landraces cultivated commercially and in backyards in Nuevo Leon are phenologically and morphologically distinct (Gutiérrez et al., 2009; Acosta et al., 2012; 2013); this was confirmed by Álvarez et al. (2018), reported a genetic diversity of $84 \%$ among them. Aramberri and Zaragoza in the southern region; Sabinas Hidalgo, Bustamante, San Nicolas de Los Garza, and Monterrey in the northern region; Santiago, Allende, Rayones, Montemorelos, General Teran, Linares, and Hualahuises in the central region of Nuevo Leon are traditional centers of production of creole avocado. Economically and genetically the most important are Aramberri, Zaragoza, Sabinas Hidalgo, and Bustamante (Acosta et al., 2012; 2013). The south of Nuevo Leon is considered an important region for experimentation, introduction, and genetic improvement, also as depositary of genetic diversity (Gutiérrez et al., 2009) and source for pest-resistant genes (Sánchez, 1999).

The fruit demanded for local consumption (Rincón et al., 2011) is selected by the potential of their pulp to elaborate pharmacological products (Kritchevsky et al., 2003; Ortiz et al., 2004). High oil content, proteins, vitamins, minerals, and fatty acids are fruit properties that motivate greater human consumption and appreciation for the fruit's nutraceutical properties has risen (Martin et al., 2011). There are a number of avocado landraces that can 
be considered promissory, regarding their content of polyunsaturated fatty acids (PUFA), which is highly desirable in foods recommended for prevention of cardiovascular problems (Osborn and Akoh, 2002). It is remarkable that omega-3 (linolenic acid) and Omega 6 (linoleic acid) fatty acids are of primary importance for human health.

From the point of view of health, one of the characteristics exploited to promote avocado consumption is the degree of unsaturation (DU) of the oil, which is determined by the amount of oleic acid (Carvalho et al., 2015). However, the presence of oleic acid is not the main characteristic from the point of view of health. It has been shown that the higher the oleic/linoleic $(\mathrm{O} / \mathrm{L})$ ratio in avocado oil, it is better for health, in particular by its contribution to the solution of cardiovascular diseases (Hwang et al., 1997). Avocado fruit is considered food rich in nutrients, with high oil content, intermediate quantity of saturated fatty acids, and polyunsaturated fatty acids, along with a high amount of monounsaturated fatty acids content. Those are agree with the Duester (2000) study for the "Hass" avocado. It is eminently desirable that the saturated fatty acids content be as low as possible, since it can contribute to a reduction in cardiovascular problems (Martin et al., 2011). Characteristic that is very attractive given that in a study of women with type 2 diabetes, demonstrate that a monounsaturated fat diet rich in avocado resulted in significantly lowered plasma triglycerides (Lerman-Garber et al., 1994), and can modify the HDL-C structure and convert LDL-C back to its nonoxidized form (Mendez and Hernandez. 2007). The objective of this study was to determine the variability in total oil content and fatty acid profile of creole avocados from Nuevo Leon, Mexico.

\section{Materials and methods}

\section{Plant materials}

During the summer-fall of 2016,36 avocado landraces (Persea americana var. drymifolia) included in this study, were collected from commercial and backyard orchards located in the municipalities of Aramberri and Zaragoza in the southern region, along with Sabinas Hidalgo and Bustamante in the northern region of Nuevo Leon State. Cultivars in the southern region represented the greatest genetic diversity among landraces in that area of the state (Acosta et al., 2012). This study also included the commercial "Hass" variety as a control; the "Hass" fruit was provided by the Avocado National Program of the Instituto Nacional de Investigaciones Forestales, Agrícolas y Pecuarias (INIFAP).

\section{Oil content and fatty acids profile}

Chemical characterizations were carried out in the Laboratory of Fruit Physiology at the Bajío experimental field, INIFAP. A duplicate sample of mature avocado fruit from each genotype was evaluated. The analysis included total oil content and a fatty acid profile which included two saturated fatty acids (SFA), palmitic and stearic; two monounsaturated fatty acids (MUFA), oleic and palmitoleic; and two polyunsaturated fatty acids (PUFA), linoleic y linolenic; this analysis was conducted according to chemical descriptors for avocado provided by the International Plant Genetic Resources Institute (1995). Total oil content was determined using the method 920.85 described by the Association of Official Analytical Chemists (AOAC, 2016). The fatty acid profile (including SFA, MUFA and PUFA) was obtained using gas chromatography-mass spectrometry (GC-MS), with a standard SUPELCO (\# 18919) mixture dissolved in hexane concentrated at $0.01 \%-0.1 \%(\mathrm{w} / \mathrm{v})$ (Quintela et al., 2012). $15 \mathrm{mg}$ fruit samples were placed in the vials and $5 \mathrm{ml}$ of hexane, plus $50 \mu 1$ of potassium hydroxide in methanol (HPLC grade, $2 \mathrm{~N}$ ) were added. The vials were sealed and shaken for $30 \mathrm{~s}$; and then, were centrifuged for $5 \mathrm{~min}$ at $7000 \mathrm{rpm}$. Then $2 \mathrm{ml}$ of supernatant were transferred to another vial for the gas chromatography analysis. The analysis was performed in a gas chromatography, equipped with a mass spectrometry detector (MS, 5973). The injection method was in a split mode (1/50) and a self-sampler was used. The column used was $100 \mathrm{~m} \mathrm{X} 0.250 \mathrm{~mm} 0.20 \mu \mathrm{m} \mathrm{HP}-88$ 
(J\&W 112-88A7). Running conditions were: inlet temperature of $250{ }^{\circ} \mathrm{C}$, injection volume of $1 \mu \mathrm{l}$, using helium as a carrier gas at a constant flow of $1 \mathrm{ml} \mathrm{min}^{-1}$. Ramp temperature in the oven was programmed as follows: 120 ${ }^{\circ} \mathrm{C}, 1 \mathrm{~min}, 10{ }^{\circ} \mathrm{C}$ per minute until $175^{\circ} \mathrm{C}, 10 \mathrm{~min}, 5^{\circ} \mathrm{C}$ per minute until $210{ }^{\circ} \mathrm{C}, 5 \mathrm{~min}, 5{ }^{\circ} \mathrm{C}$ per minute at $23{ }^{\circ} \mathrm{C}, 5$ min. Detector temperature was programmed at $260^{\circ} \mathrm{C}$. It was used a mixture of fatty acids (SIGMA) which has been already esterify by the supplier.

\section{Statistical analysis}

Data on total oil content and the fatty acid profile of avocado harvested in two different regions of Mexico, was analyzed in a completely randomized experimental design having two replicates, with 36 avocado landraces as treatments, using the SAS program, version 9.2, by the Tukey test $(\mathrm{p}<0.05)$ (SAS Institute Inc., 2010). In order to establish relationships between variables, reduce the dimensionality of the data, analyze the dispersion of the materials (Manly, 1986), and group similar genotypes, analysis of main components and conglomerates was carried out (Ward, 1963). The groups obtained were compared using the Hottelling $\mathrm{T}^{2}$ test (Johnson and Wichern, 1988) and the variables between groups through the student t. The analyzes were carried out with the Statistica program ver. 6.0 (Statistica, 2005).

\section{Results}

\section{Total oil content}

Total oil content showed a significant difference $(\mathrm{p} \leq 0.05)$ among avocado landraces of both regions. This content was higher in the southern landraces compared with those of the northern region (Tables 1 and 2). The greatest variability in total oil content was also found among landraces in the southern region; the highest standard deviation (6.00) was registered by the genotype "Platano temprano" (Table 1).

The values of the total oil content among creoles avocados from the southern region ranged from $35.0 \%$ in the genotype "Huevo de toro" to $69.7 \%$ in the genotype "Platano grueso-2" and in the northern region from 30.3 $\%$ in genotype "Especial" to $48.8 \%$ for "Chapeño". The total average of oil content for genotypes in the southern region was greater (53.97\%) compared with those in the north (39.03\%). Most avocado landraces in both regions showed the total oil content lower than that in the "Hass" variety (63.90\%); exceptions in the southern region were "Platano grueso-2", "Calabo", and "Tamaulipas" (Table 1).

\section{Fatty acids profile}

Avocado landraces showed an intermediate content of satured fatty acids (SFA) (18.82-21.43 g) and polyunsatured fatty acids (PUFA) (17.38-18.84 g), but a higher content of monounsatured fatty acids (MUFA) (59.75-52.78 g) (Table 1). It was not possible to determine which fatty acids were found in a small fraction of the avocado oil.

Significant differences $(\mathrm{p} \leq 0.05)$ were found in the content of fatty acids among the creole avocados in both regions (Tables 1 and 2). The greatest variability was observed in the southern region where the highest values were recorded for palmitic acid ( $\mathrm{SD}=3.20)$ and linoleic acid $(\mathrm{SD}=6.40)$ in "Platano temprano"; for stearic acid $(\mathrm{SD}=0.14)$ in "Mantequilla"; for palmitoleic acid $(\mathrm{SD}=1.80)$ and oleic acid $(\mathrm{SD}=9.20)$ in "Hule"; and for linolenic acid $(\mathrm{SD}=0.40)$ in "Platano delgado" (Table 1). 


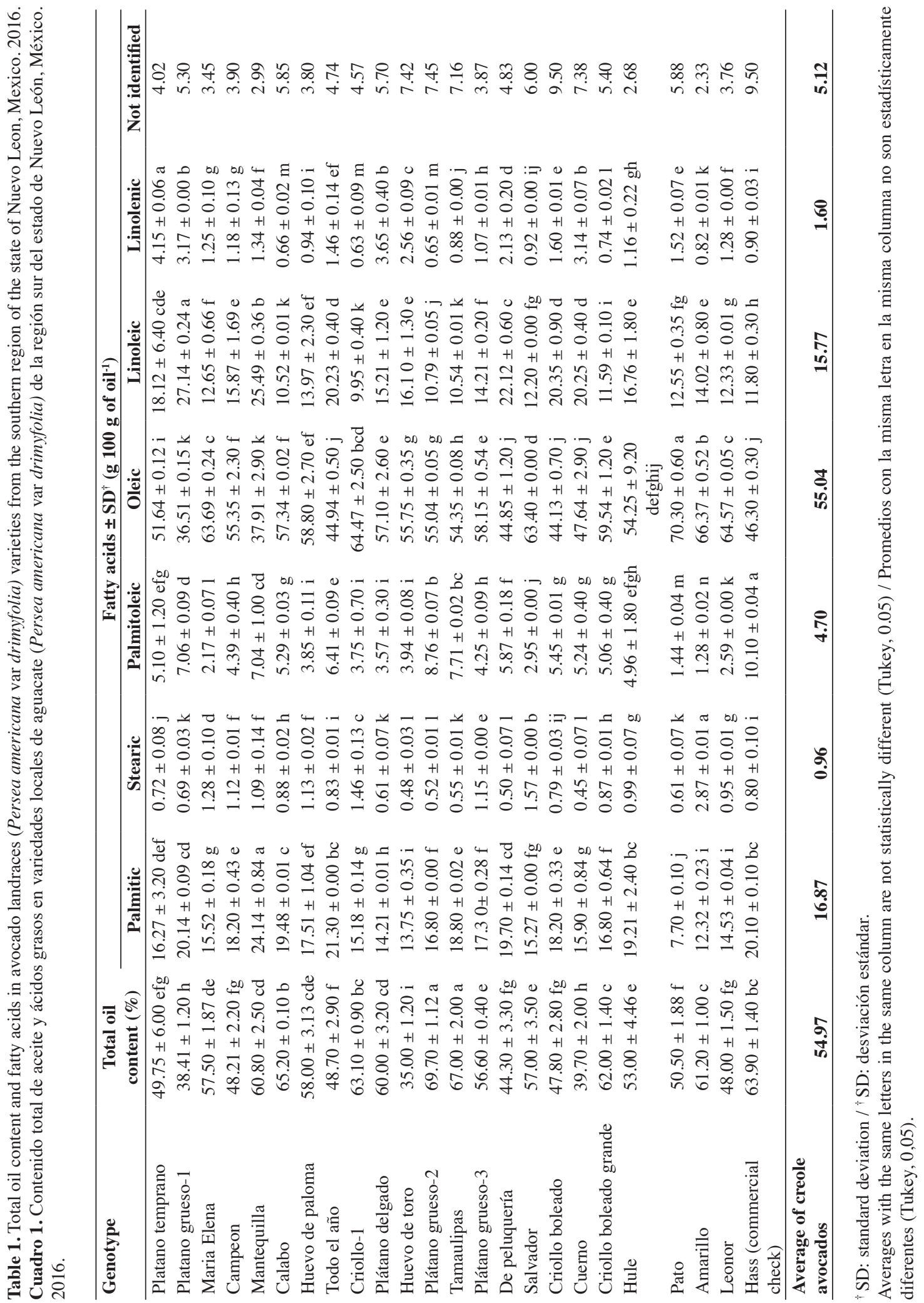




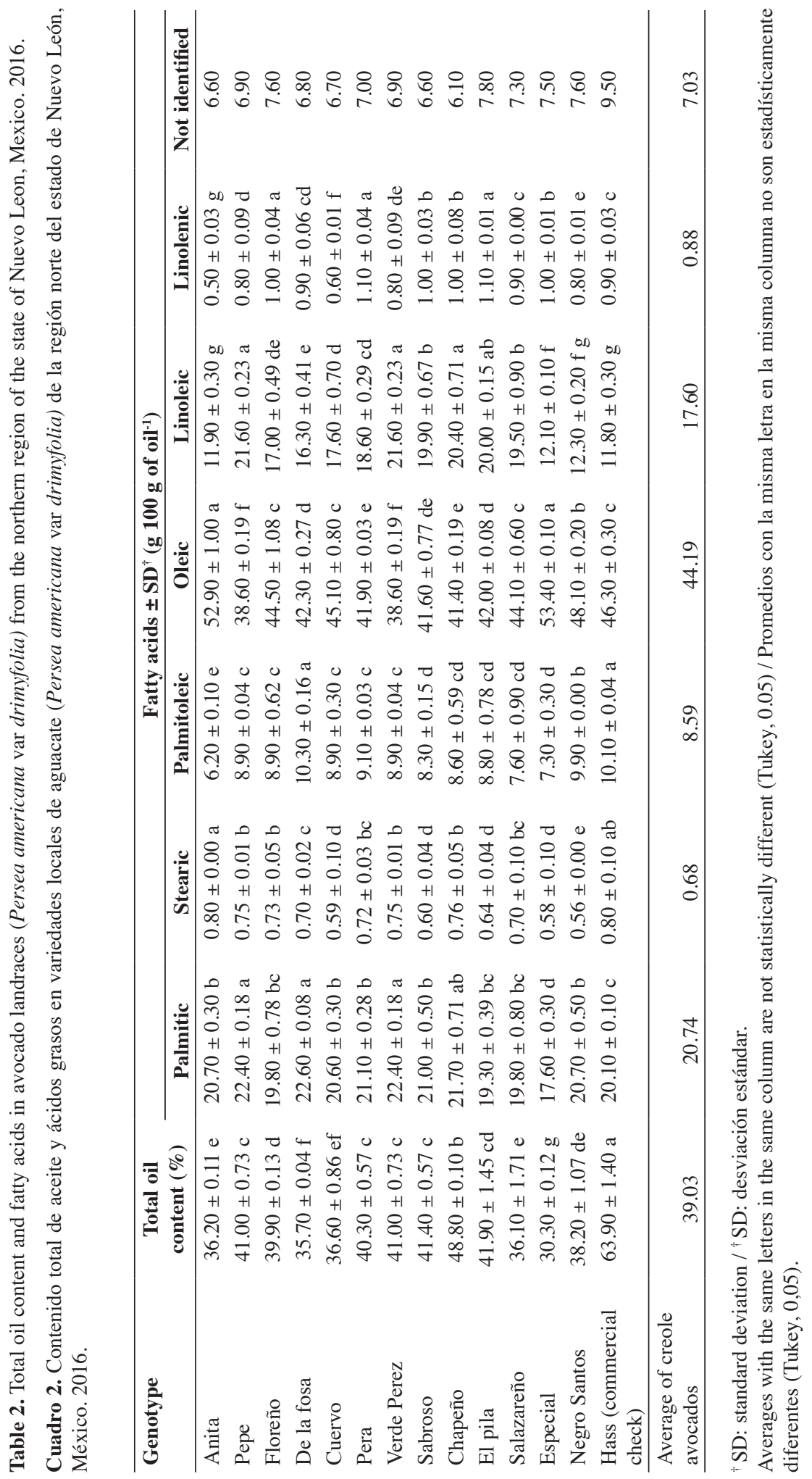




\section{Saturated fatty acids}

Palmitic acid content registered high variability among cultivars in both regions; values in the southern region varied from $7.70 \mathrm{~g}$ for cultivar "Pato" to $24.14 \mathrm{~g}$ for "Mantequilla", and in the northern region the range was from $17.60 \mathrm{~g}$ for cultivar "Especial" to $22.60 \mathrm{~g}$ in "De la fosa" (Table 1).

The palmitic acid average for cultivars in the southern region was lower (17.00 g) compared with the average of those in the northern region (20.70 g). It content was lower in most landraces than in the "Hass" avocado, except for the cultivars "María Elena", "Campeón", "Mantequilla", "Huevo de paloma", "Criollo-1", "Platano grueso-3", "Salvador", "Hule", "Amarillo", and "Pato" in the southern region, and in the northern region, only "Anita" showed a lower content.

High variability in stearic acid content was also observed in cultivars in both regions; in the southern region values ranged from $0.45 \mathrm{~g}$ for the cultivar "Cuerno" to $2.87 \mathrm{~g}$ for "Amarillo", and in the north from $0.56 \mathrm{~g}$ for the cultivar "Negro Santos" to $0.80 \mathrm{~g}$ for "Anita". The average value of stearic acid in the southern region was higher $(0.96 \mathrm{~g})$ compared with the average in the northern region $(0.68 \mathrm{~g})$ (Tables 1 and 2).

\section{Monounsaturated fatty acids}

Great variability in the content of palmitoleic acid was also apparent among landraces in both regions. Values in the southern region range from $1.28 \mathrm{~g}$ for the cultivar "Amarillo" to $8.76 \mathrm{~g}$ for "Platano grueso-2", and in the northern region from $6.20 \mathrm{~g}$ for the cultivar "Anita" to $10.30 \mathrm{~g}$ for "De la fosa". The average value of cultivars by region indicated that palmitoleic acid content was lower in the southern region $(4.70 \mathrm{~g})$ compared with the northern region $(8.59 \mathrm{~g})$. All avocado landraces in the two regions showed less palmitoleic acid content than the "Hass" variety, except for the cultivar "De la fosa" of the northern region (Table 1).

Oleic acid content showed a similar trend in variability among landraces from both regions, with values in the southern region ranging from $36.51 \mathrm{~g}$ for the cultivar "Platano grueso- 1 " to $70.30 \mathrm{~g}$ for "Pato", and in the northern region from $38.60 \mathrm{~g}$ for the cultivars "Pepe" and "Verde Perez" to $53.40 \mathrm{~g}$ for "Especial". The average value for the content of this fatty acid was higher in the southern region (55.04 g) compared with the northern region (44.19 g). Most landraces in the southern region showed a higher oleic acid content than the "Hass" variety, except for the cultivars "Platano grueso-1", "Mantequilla", "Todo el año", "de Peluquería", and "Criollo boleado"; however, in the northern region, most varieties showed lower oleic acid content than the "Hass", except for the cultivars "Anita", "Especial", and "Negro Santos" (Tables 1 and 2).

\section{Polyunsaturated fatty acids}

In this study, most landraces in both regions registered a significantly higher content of linoleic acid than the commercial "Hass" variety (11.80) except "Calabo", "Criollo-1", "Platano grueso-2", "Tamaulipas", and "Criollo boleado grande" in the southern region. Conversely, in the north all cultivars showed a linoleic acid content higher than the "Hass" variety (Tables 1 and 2); however, all avocado landraces including the "Hass" variety showed a very low linolenic acid content.

Most avocado landraces originating from the southern region registered higher linolenic acid content than the "Hass" variety, except "Calabo", "Criollo-1", "Platano grueso-2", "Tamaulipas", "Criollo boleado grande", and "Amarillo"; only the cultivars "Floreño", "Sabroso", "Chapeño", "El pila", and "Especial" originated in the northern region showed greater linolenic acid content than "Hass". The O/L ratios in all samples analyzed in the present work, were higher than 1 and some landraces shower an O/L ratio for up to six times; examples are "Criollo 
1" (6.48), "Calabo" (5.45), "Criollo boleado grande" (5.14), and "Maria Elena" (5.03) from the south and "Anita" (4.45) and "Especial" (4.41) from the northern regions of Nuevo Leon (Tables 1 and 2).

\section{Analysis of main components and conglomerates}

According to the analysis of principal components, the first component detected that the most opposite relationships were between oleic acid content versus palmitic and palmitoleic acids content, i.e. those materials with a high content of oleic acid will have lower contents of palmitic and palmitoleic acids. In the second component linolenic and linoleic acids contents were detected as the variables that contributed the most to this component; for example, there is a positive association in such a way that the materials with the highest content of linoleic acid will have higher linolenic acid content (Figure 1). In the second quadrant, the high association between oleic, stearic and total oils is observed, with oleic acid predominating.

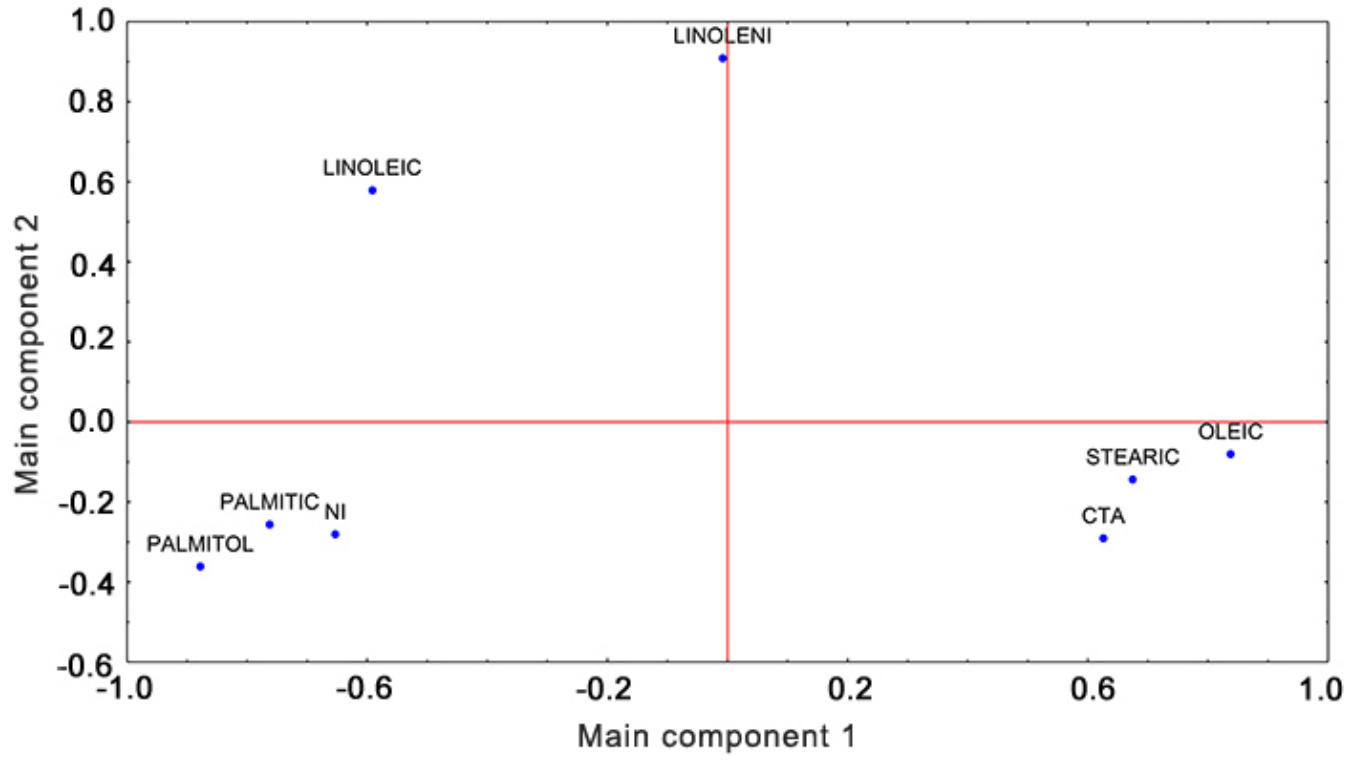

Figure 1. Distribution of the totaal oil and fatty acid content of creole avocados (Persea americana var drimyfolia) for two main components. Nuevo Leon, Mexico. 2016.

LINOLEIC: linoleic acid, LINOLENI: linolenic acid, PALMITIC: palmitic acid, PALMITOL: palmitoleic acid, OLEIC: oleic acid, STEARIC: stearic acid, CTA: total oil content, NI: unidentified acids

Figura 1. Distribución del contenido total de aceites y ácidos grasos de aguacates criollos (Persea americana var drimyfolia) para dos componentes principales. Nuevo León, México. 2016.

LINOLEIC: ácido linoleico, LINOLENI: ácido linolénico, PALMITIC: ácido palmítico, PALMITOL: ácido palmitoleico, OLEIC: ácido oleico, STEARIC: ácido esteárico, CTA: contenido total de aceite, NI: ácidos no identificados.

When the materials were graphed based on the main attributes that were listed in the quadrants of Figure 1, the genotypes; "Amarillo", "Pato", "Maria Elena", "Leonor", "Platano delgado", "Platano temprano", "Huevo de toro", "Hule", and "Campeón", were located in the second quadrant and have high concentrations of oleic, stearic acids and total oils, but they contain low concentrations of linoleic and linolenic acids (Figure 2). 


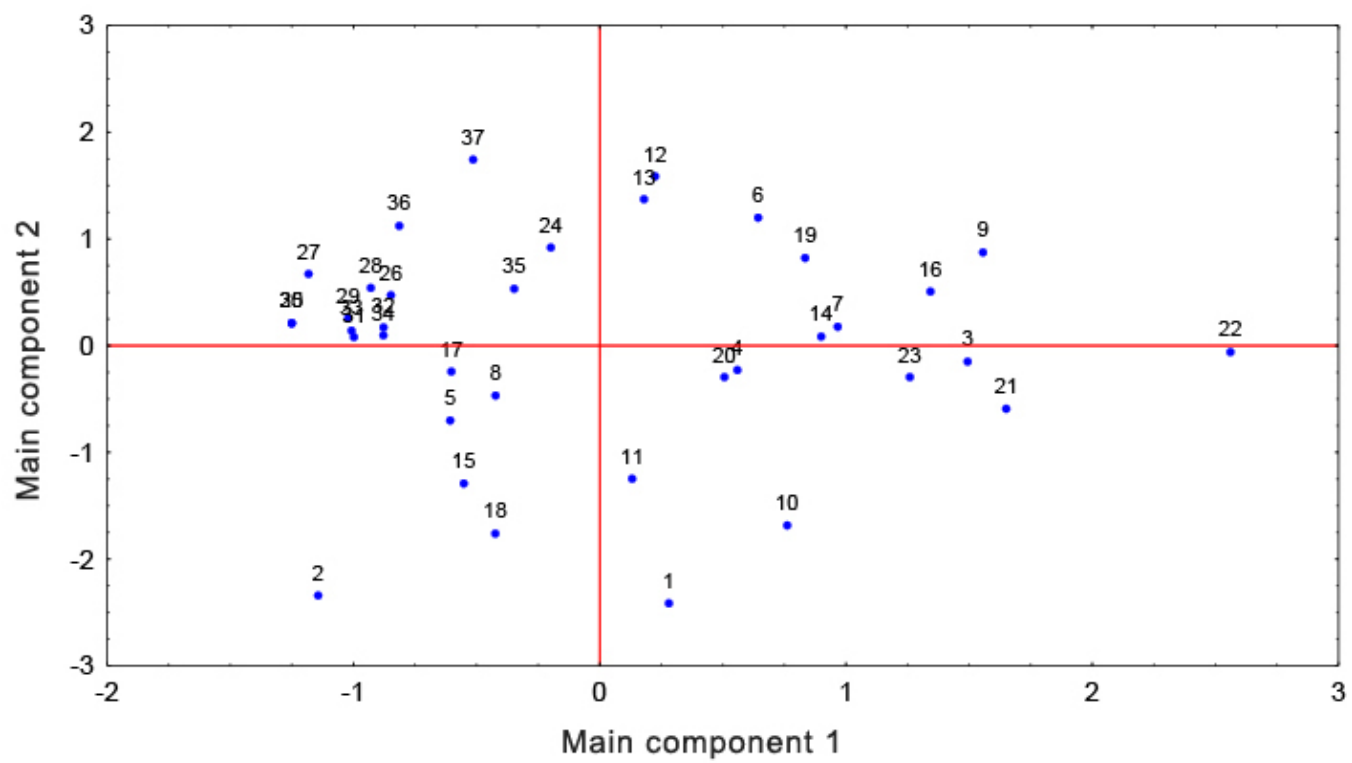

Figure 2. Distribution of creole avocado genotypes (Persea americana var drimyfolia) based on the total content of oils and fatty acids, for two main components. Nuevo Leon, Mexico. 2016.

1: "Platano temprano", 2: "Platano grueso", 3: "Maria Elena", 4: "Campeon", 5: "Mantequilla", 6: "Calabo", 7: "Huevo de paloma", 8: "Todo el año", 9: "Criollo-1", 10: "Platano delgado", 11: "Huevo de toro", 12: "Platano grueso-2", 13: "Tamaulipas", 14: "Platano grueso-3", 15: "De peluqueria", 16: "Salvador", 17: "Criollo boleado", 18: "Cuerno", 19: "Criollo boleado grande", 20: "Hule", 21: "Pato", 22: "Amarillo", 23: "Leonor", 24: "Anita", 25: "Pepe", 26: "Floreño", 27: "De la fosa", 28: "Cuervo", 29: "Pera", 30: "Verde Pérez", 31: "Sabroso", 32: "Chapeño", 33: "El pila", 34: "Salazareño", 35: "Especial”, 36: "Negro Santos", 37: "Hass"

Figura 2. Distribución de genotipos de aguacate criollo (Persea americana var drimyfolia) basados en el contenido total de aceites y ácidos grasos, para dos componentes principales. Nuevo León, México. 2016.

1: Plátano temprano, 2: Plátano grueso, 3: María Elena, 4: Campeón, 5: Mantequilla, 6: Calabo, 7: Huevo de paloma, 8: Todo el año, 9: Criollo-1, 10: Plátano delgado, 11: Huevo de toro, 12: Plátano grueso-2, 13: Tamaulipas, 14: Plátano grueso-3, 15: De peluquería, 16: Salvador, 17: Criollo boleado, 18: Cuerno, 19: Criollo boleado grande, 20: Hule, 21: Pato, 22: Amarillo, 23: Leonor, 24: Anita, 25: Pepe, 26: Floreño, 27: De la fosa, 28: Cuervo, 29: Pera, 30: Verde Pérez, 31: Sabroso, 32: Chapeño, 33: El pila, 34: Salazareño, 35: Especial, 36: Negro Santos, 37: Hass.

The genotypes; "Anita", "Especial", "Negro Santos", "Cuervo", "Floreño", "De la fosa", "Pepe", "Verde Pérez", "Pera", "El pila", "Sabroso" and "Salazareño", were located in the fourth quadrant and have high concentration of linoleic and linolenic acids, but contain low concentrations of oleic, stearic acids and total oils (Figure 2), and all correspond to the northern region. In the case of genotypes; "Platano grueso-1", "Mantequilla", "Todo el año", "De peluquería", "Criollo boleado" and "Cuerno", were located in the third quadrant and have high concentrations of palmitic, palmitoleic and unidentified oils, and like the materials of the northern region, contain low concentrations of oleic, stearic and total oils (Figure 2).

A better characterization and grouping of the evaluated genotypes was obtained with the cluster analysis using the Ward methodology, which allowed the identification of six groups (Figure 3).

The genotypes located in group one have, generally, a low content of total oils with the exception of the variety "Platano delgado" (60.00), but have a high content of oleic acid and of monounsaturated acids. In addition, "Platano delgado" have low concentrations of stearic acid which is a desirable and highly relevant characteristic. The genotypes that make up group two, are a good source of total oil and oleic acid, but have high levels of 


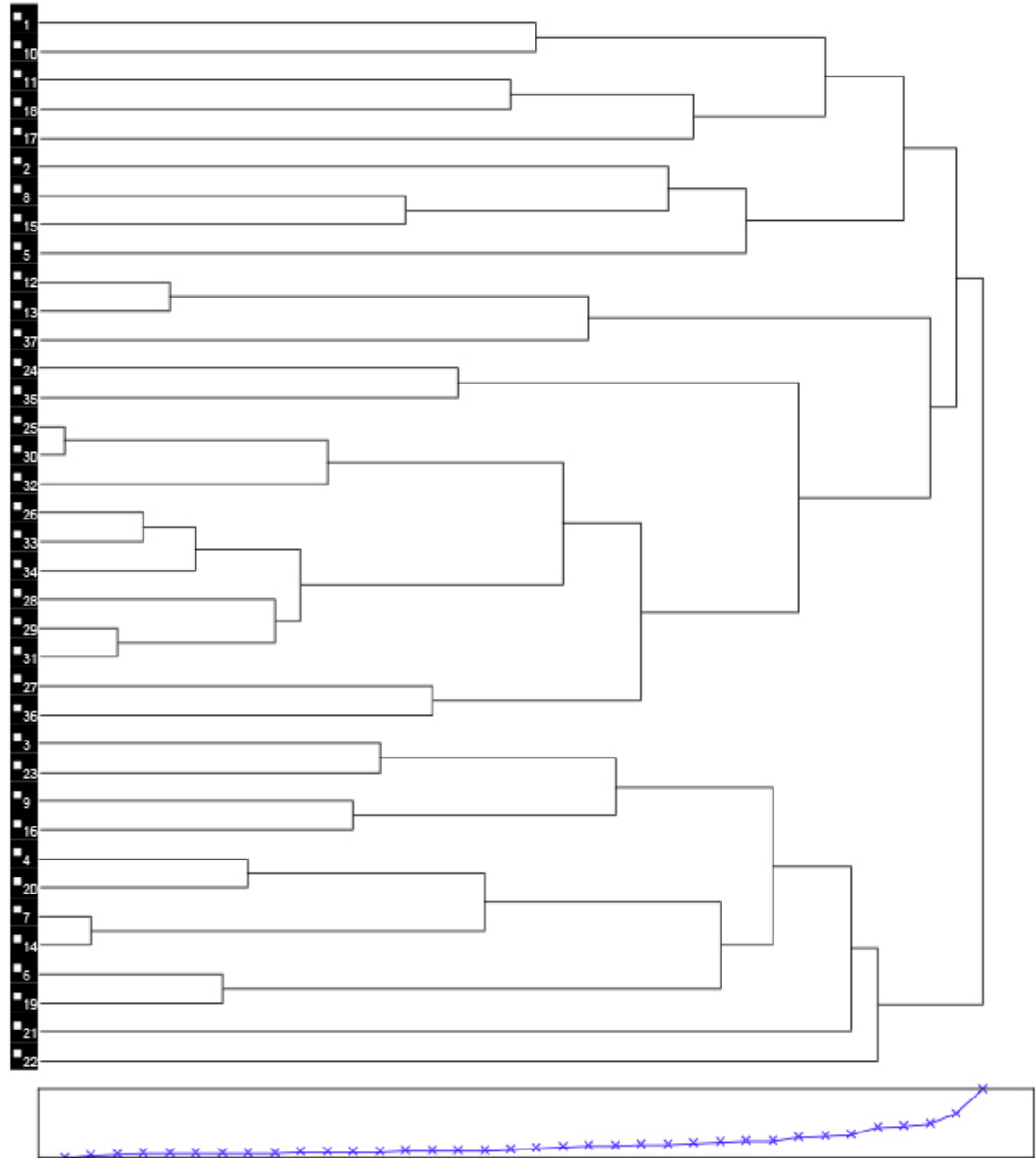

Figure 3. Dendrogram generated by conglomerate analysis, based on the total content of oils and fatty acids of creole avocado genotypes (Persea americana var drimyfolia). Nuevo Leon, Mexico. 2016.

1: "Platano temprano", 2: "Platano grueso", 3: "Maria Elena", 4: "Campeon", 5: "Mantequilla", 6: "Calabo", 7: "Huevo de paloma", 8: "Todo el año", 9: "Criollo-1", 10: "Platano delgado", 11: "Huevo de toro", 12: "Platano grueso-2", 13: "Tamaulipas", 14: "Platano grueso-3", 15: "De peluqueria", 16: "Salvador", 17: "Criollo boleado", 18: "Cuerno", 19: "Criollo boleado grande", 20: "Hule", 21: "Pato", 22: “Amarillo", 23: "Leonor", 24: "Anita", 25: "Pepe", 26: "Floreño", 27: "De la fosa", 28: "Cuervo", 29: "Pera", 30: "Verde Perez", 31: "Sabroso", 32: "Chapeño", 33: "El pila", 34: "Salazareño", 35: "Especial”, 36: "Negro Santos", 37: "Hass"

Figura 3. Dendograma generado por análisis de conglomerados, basado en el contenido total de aceites y ácidos grasos de genotipos de aguacate criollo (Persea americana var drimyfolia). Nuevo León, México. 2016.

1: Plátano temprano, 2: Plátano grueso, 3: María Elena, 4: Campeón, 5: Mantequilla, 6: Calabo, 7: Huevo de paloma, 8: Todo el año, 9: Criollo-1, 10: Plátano delgado, 11: Huevo de toro, 12: Plátano grueso-2, 13: Tamaulipas, 14: Plátano grueso-3, 15: De peluqería, 16: Salvador, 17: Criollo boleado, 18: Cuerno, 19: Criollo boleado grande, 20: Hule, 21: Pato, 22: Amarillo, 23: Leonor, 24: Anita, 25: Pepe, 26: Floreño, 27: De la fosa, 28: Cuervo, 29: Pera, 30: Verde Pérez, 31: Sabroso, 32: Chapeño, 33: El pila, 34: Salazareño, 35: Especial, 36: Negro Santos, 37: Hass.

stearic acid, which is an undesirable condition. Creole avocados with higher total oil contents were located in group three (Platano grueso-2, "Tamaulipas") predominating oleic, palmitic and palmitoleic acids, but have low monounsaturated acid contents. 
Group four included all the materials collected in the northern, those materials are characterized by their positive relationship in the content of linoleic and linolenic acids, in addition, have a low content of stearic acid, but the content of total oils is low. Group five included materials with a high content of monounsaturated acids, but with a low concentration of total oils with the exception of the "Mantequilla" genotype (60.80), and high content of palmitic acid, which being a saturated acid, is not a desirable feature. Group six was made up only of the "Amarillo" genotype, which had the second highest amount of oleic acid (66.37), but it contains the highest concentration of stearic acid (2.87).

\section{Discussion}

Data obtained suggest that oil content and fatty acids were important variables to characterize creole avocados from Nuevo Leon. Average total oil content registered for landraces in both regions was greater than the value reported by Dreher and Davenport (2013) for the "Hass" avocado (15.4\%). These results regarding morphological fruit characteristics agree with those reported by Gutiérrez et al. (2009) and Acosta et al. (2012), as well as those recently reported for genetic diversity of avocado landraces from the same region of the study (Gutiérrez et al., 2015; Álvarez et al., 2018). The oil content of avocado landraces reported here is similar to Pistachios (44.9) and almost similar to Almonds (52\%) (USDA, 2011). Over the past 30 years, the public perception was that consuming high amounts of fat can lead to weight gain. However, a long-term clinical study demonstrated that a moderate fat diet favors weight loss and the reduction of chronical diseases (Sacks et al., 2009). Moreover, the US departments of Agriculture and Health and Human Services declared that "strong and consistent evidence indicates that dietary patterns that are relatively low in energy density improve weight loss and weight maintenance among adults" (USDA and HHS, 2010). Avocado have a medium energy density of $2.7 \mathrm{kcal} \mathrm{g}^{-1}$, and together with fiber and oil appears to enhance satiety (Wien et. al., 2011) and can support weight control similar to fruits.

These findings indicate that in addition to a higher total oil content than that registered by the "Hass" variety in some avocado landraces in the southern region, such as "Platano grueso-2", "Tamaulipas", and "Calabo", there are also several cultivars which have important chemical characteristics such as low saturated fatty acids content and high amounts of monounsaturated fatty acids and polyunsaturated fatty acids. Results confirm that traditional avocado production systems in the southern region are depositories of a unique genetic diversity containing genes not completely studied (Gutiérrez et al., 2009; 2015; Álvarez et al., 2018).

The average content of oleic acid reported for cultivars of both regions in this study was slightly lower than the $80 \%$ value for the "Hass", as reported by Pérez et al. (2005). Importantly, this fatty acid is present in all vegetable oils and fats; and its the main component in some oils such olive, canola, and avocado.

In both regions of the study, the intermediate polyunsaturated fatty acids content recorded is slightly higher than that reported for the "Hass" avocado, but it is much higher than that found in olive and coconut oil. This value, however, is lower than that for corn, cotton, soybean, and sunflower oil. Avocado oil generally has a low linolenic acid content $(<1 \%)$ (Mataix and Gil, 2002); however, this value is less than that recorded for several cultivars originated in the municipalities of both regions. Among the vegetable oils, only canola and soybean contain appreciable amounts of linolenic acid (McDonald, 2000). It has been reported that foods with a low acid ratio of linolenic: linoleic (n-3: n-6) are related to heart problems, obesity, and cancer (Martin et al., 2011).

Given its fatty acid composition, avocado oil garners nutritional recommendations focused on reducing the amount of saturated fat in diets; it is characterized by a low proportion of saturated fatty acids, high content of oleic acid (can reach up to $80 \%$ ), and an acceptable level of non-cholesterol polyunsaturated fatty acids (Pérez et al., 2005). It has been reported that the content of oleic acid for avocado "Hass" from Chile ranges from 57 to $61 \%$, from Spain from 54 to $60 \%$, and from Peru from 40 to $47 \%$ (Donetti y Terry, 2014). These authors hypothesized 
that oleic acid could be a marker of origin; in this regard, Guzmán-Maldonado et al. (2017) hypothesized that a range of oil content between 43.1 to $59.7 \%$ could be a marker of origin for Mexican avocado. The oleic acid of fifteen landraces reported in this study, ranges from 44.13 to $59.5 \%$, then such materials can be placed in the middle of the fruit of Peru and that of Spain could serve as a marker of origin, at least for the southern region of Nuevo Leon. The same was observed for six landraces harvested in the northern region of the same state.

Results indicated that avocado landraces with less (palmitic and stearic acid) and a greater amount of monounsaturated fatty acids (palmitoleic and oleic) and polyunsaturated fatty acids (linoleic and linolenic) can be selected as an alternative to the corresponding values in the "Hass" variety. It seems desirable, therefore, to select avocado genotypes showing higher linolenic acid content and a high ratio of linoleic acid (Mataix and Gil, 2002). It is interesting that among vegetable oils only canola and soybean contain appreciable amounts of linolenic acid (McDonald, 2000).

Under that selection criterion, avocado landraces can be grouped into four categories: The first category being outstanding cultivars with five positive attributes and only one negative in the proportions of fatty acids; these cultivars include "Platano temprano", "Platano delgado", "Huevo de toro", "Cuerno" (all included in group one), and "Pato" of the southern region, along with "Especial" from the northern region. The second category consisting of intermediate response cultivars, with four positive attributes and two considered negative; listed here are "María Elena", "Campeón", "Huevo de Paloma", "Platano grueso-3", "Salvador", "Hule", "Leonor" (included in group second), "Criollo boleado" and "De peluquería" (these materials were included in different groups, but have similar characteristics since according to the analysis of the main components that were included in the third quadrant), from the southern region along with "Floreño" and "El Pila" from the north, which are closely related according to the analysis of conglomerates. The third category includes cultivars with three positive attributes and two that are negatives; included here are "Platano grueso-1", "Platano grueso-2", "Tamaulipas" (these last two together with the commercial variety "Hass" constitute group three according to the analysis of conglomerates), and "Amarillo" from the south, along with "Pera" "Sabroso", "Chapeño", "Salazareño", and "Negro Santos" in the northern region, emphasizing by its close relation the "Pera" and "Sabroso" genotypes according to the analysis of conglomerates. The fourth category embraces those cultivars with only two positive attributes and three considered negative; included here are "Mantequilla", "Calabo", "Todo el año", "Criollo-1", and "Criollo boleado grande" in the southern region, along with "Anita", "Pepe", "De la fosa", "Cuervo", and "Verde Perez" from the north. This last group was the most irregular since it includes genotypes that formed different groups according to the cluster analysis and are considered the least desirable for their incorporation into a breeding program.

\section{Conclusions}

High variability in the content of total oils and fatty acids of the creole avocados of Nuevo Leon was recorded. It can be inferred that this variability is due more to the characteristics of the materials than to the region where were collected. Among the outstanding cultivars are "Platano temprano", "Platano delgado", "Huevo de toro", "Cuerno" and "Pato" from the southern region and "Especial" from the northern region, since the content of oleic, linoleic and linolenic acids was higher (17.28, 24.93 and $66.29 \%$, respectively), and the content of stearic acid was lower (28.12\%) in relation to that registered in the "Hass" commercial variety.

\section{Cited literature}

Acosta, E., I. Torres, e I.H. Almeyda. 2012. Evaluación de aguacates criollos en Nuevo León, México: Región Sur. Rev. Mex. Cienc. Agríc. 3:245-257. 
Acosta, E., I.H Almeyda, e I. Hernández. 2013. Evaluación de aguacates criollos en Nuevo León, México: Región Norte. Rev. Mex. Cienc. Agríc. 4:531-542.

Álvarez, M.G., V. Pecina, E. Acosta, e I.H. Almeyda. 2018. Evaluación molecular del aguacate criollo (Persea americana Mill) en Nuevo León, México. Rev. Colomb. Biotecnol. 20(2):38-46. doi:10.15446/rev.colomb.biote.v20n2.69551

AOAC (Association of Official Analytical Chemists). 2016. Official methods of analysis of the Association of Official Analytical Chemists. 20th ed. AOAC, Rockville, USA.

Barrientos, A.F., J.C. Reyes, y J.J. Aguilar. 2010. Manual gráfico para la descripción varietal de Aguacate. Servicio Nacional de Inspección y Certificación de Semillas (SNICS), Secretaría de Agricultura, Ganadería, Desarrollo Rural, Pesca y Alimentación (SAGARPA), y Universidad Autónoma de Chapingo (UACh), Tlalnepantla, Estado de México, MEX.

Carvalho, C.P., J. Bernal, M.A. Velásquez, and J.R. Cartagena. 2015. Fatty acid content of avocados (Persea americana Mill. cv. Hass) in relation to orchard altitude and fruit maturity stage. Agron. Colomb. 33:220-227. doi:10.15446/agron.colomb. v33n2.49902.

Donetti, M., and L. Terry. 2014. Biochemical markers defining growing area and ripening stage of imported avocado fruit cv. "Hass". J. Food Compos. Anal. 34:90-98. doi:10.1016/j.jfca.2013.11.011

Dreher, M.L., and A.D. Davenport. 2013. "Hass" avodado composition and potential heralt effects. Crit. Rev. Food Sci. Nutr. 53:738-750. doi:10.1080/10408398.2011.556759

Duester, K.C. 2000. Avocados: A look beyond basic nutrition for one of nature's whole foods. Nutr. Today 35:151-157.

Fiedler, J., G. Bufler, and F. Bangerth. 1998. Genetic relationships of avocado (Persea americana Mill.) using RAPD markers. Euphytica 101:249-255. doi:10.1023/A:1018321928400.pdf

Gutiérrez, A., J. Martínez, E.A. García, L. Iracheta, J.D. Ocampo, e I.M. Cerda. 2009. Estudio de la diversidad genética del aguacate en Nuevo León, México. Rev. Fitotec. Mex. 32:9-18.

Gutiérrez, A., A. Sánchez, J.A. Torres, I.M. Cerda, and C. Ojeda. 2015. Genetic diversity of Mexican avocado in Nuevo Leon. In: M. Caliskan et al., editors, Molecular Approaches to Genetic Diversity. InTech, MEX. p. 141-159. doi:10.5772/59795.

Guzmán-Maldonado, S.H., G.J.A. Osuna, and G.J.A. Herrera. 2017. Effect of locality and maturity on the fatty acid profile of avocado "'Hass"” fruit. Rev. Mex. Cienc. Agríc. 19:3885-3896.

Hwang, D.H., P.S. Chanmugam, D.H. Hyan, M.D. Boudreau, M.M. Windhauser, R.T. Tulley, E.R. Brooks, and G.A. Bray. 1997. Does vegetable oil attenuate the beneficial effects of fish oil reducing risk factors for cardiovascular disease? Am. J. Clin. Nutr. 66:89-96. doi:10.1093/ajcn/66.1.89.

International Plant Genetic Resources Institute. 1995. Descriptors for avocado (Persea spp.). CGIAR. https://cgspace.cgiar.org/ bitstream/handle/10568/72796/Descriptors_Avocado_323.pdf?sequence=1\&isAllowed=y (accessed 15 Jun. 2018).

Johnson, R.A., and D.W. Wichern. 1988. Applied multivariate statistical analysis. 2nd ed. Prentice-Hall, Englewood Cliffs, NJ, USA.

Kritchevsky, D., S.A. Tepper, S. Wright, S.K. Czarnecki, T.A. Wilson, and R.J. Nicolosi. 2003. Cholesterol vehicle in experimental atherosclerosis 24: avocado oil. J. Amer. Coll. Nutrit. 22:52-55.

Lerman-Garber, I., S. Izhazo-Cerro, J. Zamora-Gonzalez, G. Cardoso-Saldana, and C. Posadas-Romero. 1994. Effect of a high-monounsaturated fat diet enriched with avocado in NIDDM patients. Diabetes Care 17:311-315. doi:10.2337/ diacare.17.4.311

Manly, B.F.J. 1986. Multivariate statistical methods: A primer. Chapman and Hall, London, GBR. 
McDonald, B.E. 2000. Canola oil: Nutritional properties. Canola Council of Canada, CAN. http://www.canolacouncil.org/ (accessed 15 Jun. 2014).

Martin, C., E. Butelli, K. Petroni, and C. Tonelli. 2011. Review. How can research on plants contribute to promoting human health? The Plant Cell 23:1685-1699. doi:10.1105/tpc.111.083279

Mataix, J., y A. Gil. 2002. Lípidos alimentarios. Libro Blanco de los Omega-3. Los ácidos grasos poliinsaturados omega-3 y monoinsaturados tipo oleico y su papel en la salud. Editorial Puleva, Granada, ESP.

Mendez, P.O., and G.L. Hernandez. 2007. HDL-C size and composition are modified in the rat by diet supplementation with "Hass" avocado. Arch. Cardiol. Mex. 77(1):17-24.

Newett, S.D., J.H. Grandy, and C.F. Balerdi. 2002. Cultivars and rootstocks. In: A.W. Whiley et al., editors, Avocado: Botany, production and uses. CAB Publishing, FL, USA. p. 161-187. doi:10.1079/9781845937010.0200

Ortiz, M., A.L. Dorantes, M.J. Galldnez, and E. Cárdenas. 2004. Effect of a novel oil extraction method on avocado (Persea americana Mill) pulp microstructure. Plant Foods Hum. Nutr. 59:11-14. doi:10.1007/s11130-004-0032-3

Osborn, H.T., and C.C. Akoh. 2002. Structured lipids- novel fats with medical, nutraceutical, and food applications. Comp. Rev. Food Sci. Food Saf. 1(3):110-120. doi:10.1111/j.1541-4337.2002.tb00010.x

Pérez, R.R.I., S.V. Rodríguez, y R.C. Ramírez. 2005. El aceite de aguacate y sus propiedades nutricionales. e-Gnosis 3(10):1-11.

Quintela, M., J. Báguena, G. Gotor, M.J. Blanco, and F. Broto. 2012. Estimation of the uncertainty with the results based on the validation of chromatographic analysis procedures: Application to the determination of chlorides by high performance liquid chromatography and of fatty acids by high resolution gas chromatography. J. Chromatogr. 1223(3):107-117. doi:10.1016/j.chroma.2011.11.064

Rincón, H.C.A., de la P.J. Sánchez, y G.F.J Espinosa. 2011. Caracterización química foliar de los árboles de aguacate criollo (Persea americana var. drymifolia) en los bancos de germoplasma de Michoacán, México. Rev. Mex. Biodiver. 82:395412.

Sacks, F.M., G.A. Bray, V.J. Carey, S.R. Smith, D.H. Ryan, S.D. Anton, K. McManus, C.M. Champagne, L.M. Bishop, N. Laranjo, M.S. Leboff, J.C. Rood, L. de Jonge, F.L. Greenway, C.M. Loria, E. Obarzanek, and D.A. Williamson. 2009. Comparison of weight loss diets with different compositions of fat, protein, and carbohydrates. New Engl. J. Med. 360:859-873. doi:10.1056/NEJMoa0804748

Sánchez, J.L. 1999. Recursos genéticos de aguacate (Persea americana Mill.) y especies afines en México. Rev. Chapingo Ser. Hortic. 5:7-18.

Sánchez, J.L. 2007. Identificación de marcadores asociados a la resistencia del aguacate raza mexicana (Persea americana Mill. var drymifolia) al oomiceto Phytophthora cinnamomi Rands. Tesis Ph.D., Universidad Michoacana de San Nicolás de Hidalgo, Morelia, Michoacán, MEX.

SAS Institute Inc. 2010. SAS/STAT User’s guide. Ver. 9.2 SAS Institute, Inc., Cary, NC, USA.

SAGARPA (Secretaría de Agricultura, Ganadería Desarrollo Rural, Pesca y Alimentación). 2016. México es el principal productor y exportador de aguacate en el mundo. Gobierno de México, MEX www.gob.mx/se/articulos/mexico-es-elprincipal-productor-y-exportador-de-aguacate-en-el-mundo. (consultado consultado 14 mar. 2019).

Statistica. 2005. Data analysis software system, Version 7.1. StatSoft, Inc, Tulsa, OK, USA. http://www.statsoft.com (accessed march 14, 2019).

USDA. 2011. Avocado, almond, pistachio and walnut composition. Nutrient Data Laboratory. USDA National Nutrient Database for Standard Reference. Release 24. USDA, WA, USA. 
USDA, and HHS. 2010. Report of the dietary guidelines advisory committee and the dietary guidelines for americans. Part D. Section 1: Energy balance and weight management. USDA, WA, USA.

Ward, J.H. 1963. Hierarchical grouping to optimize an objective function. J. Am. Stat. Assoc. 58:236-244.

Wien, M., E. Haddad, and J. Sabaté. 2011. Effect of incorporating avocado in meals on satiety and healthy overweight adults. In: A. Marcos et al., editors, $11^{\text {th }}$ European Conference of the Federation of the European Nutrition Societies. Karger Publishers, Berlin, GER. p. 443. 